\title{
Water quality of Angke River: Microbiological point of view
}

\author{
Conny Riana Tjampakasari, Mardiastuti H Wahid
}

\begin{abstract}
Abstrak
Penelitian ini merupakan bagian dari penelitian multidisiplin di Kali Angke. Tujuan dilakukannya penelitian ini adalah untuk mengetahui kualitas air sungai ditinjau dari aspek mikrobiologik di beberapa lokasi sepanjang Kali Angke. Lokasi yang diteliti meliputi: Duri Kosambi, Pesing Poglar, Teluk Gong, Pantai Indah Kapuk dan Muara (4 titik). Pemeriksaan dilakukan berdasarkan petunjuk standar Departemen Kesehatan, Republik Indonesia dan hasilnya disimpulkan sesuai Peraturan Pemerintah Republik Indonesia. Parameter yang digunakan dalam uji mikrobiologi adalah most probable number (MPN) dari total dan fecal coliform, yang dilakukan dalam 2 langkah: uji presumtif dan uji konfirmasi. Uji lengkap dilakukan untuk mengkonfirmasi adanya E.coli dan bakteri lain dalam air. Hasil yang didapat menunjukkan bahwa mutu air Kali Angke kurang baik dan tidak dianjurkan sebagai air minum. Berdasarkan parameter mikrobiologik, kualitas air sungai ini dikategorikan sebagai kelas 2 yang artinya hanya dapat digunakan untuk rekreasi air, pembudidayaan ikan air tawar, peternakan, mengairi pertanaman dan atau peruntukkan lain yang mempersyaratkan mutu air yang sama dengan kegunaan tersebut. Most probable number dari total coliform di daerah Pantai Indah Kapuk dan bagian luar daerah Muara lebih rendah dari daerah lainnya. Masyarakat yang tinggal di Pantai Indah Kapuk memiliki tingkat ekonomi yang lebih tinggi, dengan demikian dapat diasumsikan bahwa masyarakat ini memiliki tingkat pendidikan yang lebih tinggi dan memiliki kesadaran tentang kebersihan lingkungan yang lebih baik. Selanjutnya, air di daerah paling luar dari Muara memiliki kadar garam yang tinggi sehingga dapat membunuh bakteri-bakteri patogen. Akhir kata, kualitas air di sepanjang Kali Angke adalah air kelas dua yang tidak layak minum kecuali di daerah Pantai Indah Kapuk dan Muara yang layak minum sesudah dididihkan. (Med J Indones 2008; 17:82-7)
\end{abstract}

\begin{abstract}
This research is a part of a multidisciplinary research in the Angke River. The aim of this research is to study the river's water quality from the microbiological point of view in several locations along the Angke River. The locations under this study included: Duri Kosambi, Pesing Poglar, Teluk Gong, Pantai Indah Kapuk and Estuary (4 points). The examinations were held in term of microbiological aspects, based on the guide published by the Ministry of Health, the Republic of Indonesia and concluded according to Government Regulation. The parameter of microbiological tests was the most probability number (MPN) of total and fecal coliform. The method used was done in 2 steps: presumptive and confirmed test. Completed test was conducted to confirm the presence of E.coli and other bacteria in water. The result showed that the water quality of the Angke River was poor; therefore, it is not recommended to be used as drinking water. It is categorized as the $2^{\text {nd }}$ class quality that means it can only be used for water recreation, veterinary, showering plants and or other purposes that require the same quality of water. The MPN of total coliform at Pantai Indah Kapuk and the outer side of river mouth (estuary area) was lower than other areas. People who live in Pantai Indah Kapuk are having a higher economic level. Therefore, it can be assumed that they are more educated people who have more insight about hygiene. Further, the water at the outer side of river mouth contains a higher salt concentration that can kill pathogenic bacteria. In conclusion, the water quality of the Angke River is categorized as $2^{\text {nd }}$ class quality not recommended to be used as dringking water except the water from Pantai Indah Kapuk and estuary area that can be used as dringking water after boiling. (Med J Indones 2008; 17:82-7)
\end{abstract}

Keywords: Total coliform, fecal coliform, most probability number, E.coli

The Angke River is located at the northwest of Jakarta. This river was polluted with garbage that can cause diseases. People lived on the riverside in houses with low ceilings and muddy floors. Every year flood causes

Department of Microbiology, Faculty of Medicine, University of Indonesia, Jakarta, Indonesia serious problems during the rainy season, since this river is located in the lowlands.

Based on this fact, since 2002, Tzu Chi foundation has helped to relocate people from the Angke River to Tangerang in order to clean up the river and to give a proper life to the people. The foundation has constructed 1.100 houising units in the Great Love Village, 55-story 
buildings and schools, a free clinic, a nursing home, stores, and factories to improve their attitude, economy, culture and social behavior. Since 2005, the village has been providing drinkable tap water. They also can provide wastewater sewage treatment and recycled water for watering plants and cleaning up public areas. ${ }^{1}$

$\mathrm{Tzu}$ Chi foundation also supported a research that was organized by several faculties in University of Indonesia as an integrated research. This study is a part of the research to determine the water quality of the Angke River, by doing physical, chemical, biological, radioactive and microbiological tests. This study was conducted at the Department of Microbiology, Faculty of Medicine, University of Indonesia, and aimed to examine the quality of the Angke River water, on the microbiological aspect, by calculating the most probable number (MPN) of total and fecal coliform.

\section{METHODS}

Eight samples from different locations in the Angke River were taken on April 15 ${ }^{\text {th }}, 2007$, i.e.: Duri Kosambi, Pesing Poglar, Teluk Gong, and Pantai Indah Kapuk (1 sample each), and Muara/Estuary (4 samples from 4 different points i.e. left side of river mouth, river mouth, right side of river mouth, and outer side of river mouth).

To analyze the number of total and fecal coliform in $100 \mathrm{ml}$ water, we used the most probable number (MPN) method using the double tube method.

In the double tube method, the three basic steps to detect the presence of coliform bacteria in water are presumptive, confirmed and completed test. The tests are performed sequentially on each sample. They detect the presence of coliform bacteria (an indicator of fecal contamination), i.e. the gram-negative, nonspore-forming bacilli that ferment lactose into acid and gas that is detectable in the following 24-hour incubation period at $37^{\circ} \mathrm{C} .2,3$

In this study, only 2 steps were done., ${ }^{2,3}$

Step 1. Presumptive test (Figure 1)

- Inoculation on lactose broth medium
- If there is bubble formation, continue to confirmed test

Step 2. Confirmed test (Figure 2)

- Inoculation on brilliant green bile lactose broth (BGLB)

- To calculate the total coliform, the inoculated BGLB tubes were incubated at $35 \pm 0.5{ }^{\circ} \mathrm{C}$ for 48 hours, while for fecal coliform, the inoculated BGLB tubes were incubated at $44.5 \pm 0.2{ }^{\circ} \mathrm{C}$ for 48 hours

- Calculate the MPN of coliforms based on proportion of confirmed gassing in BGLB tubes for 5 consecutive dilutions.

To ensure the presence of $E$. coli and other bacteria in water, we conducted the completed test (Figure 3) using selective medium and biochemical test. ${ }^{2,3}$ The study was completed within 2 weeks.

The MPNs at different sampling locations were tabulated and compared to the MPNs in requirement of good quality drinking water based on the Ministry of Health recommendation ("Keputusan Menteri Kesehatan RI" 907/MENKES/SK/VII/2002, July 29, 2002) $)^{4}$, i.e.: total coliform $=0$, fecal coliform $=0, E$. coli not found.

Further, the MPNs were also compared to the MPNs in the classification of drinking water quality based on Government Regulation ("Peraturan Pemerintah Republik Indonesia" No. 82, 2001) about water quality handling and water pollution control (see table 1$){ }^{5}$

For each location, the quality of water was interpreted according to both standards. ${ }^{4,5}$

Table 1. Classification of drinking water quality

\begin{tabular}{lrrrr}
\hline & $1^{\text {st }}$ class & $2^{\text {nd }}$ class & $3^{\text {rd }}$ class & $4^{\text {th }}$ class \\
\hline Fecal coliform & 100 & 1000 & 2000 & 2000 \\
Total coliform & 1000 & 5000 & 10000 & 10000 \\
\hline
\end{tabular}




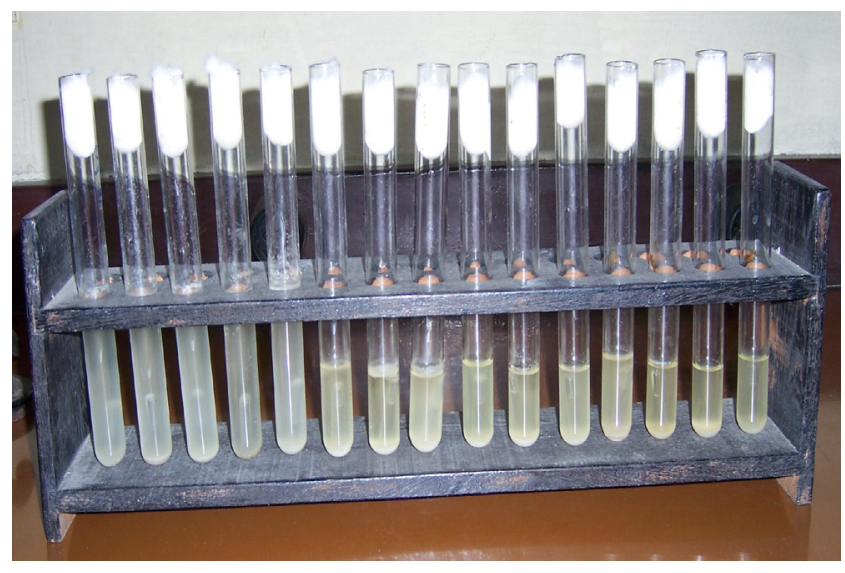

Figure 1. Presumptive test

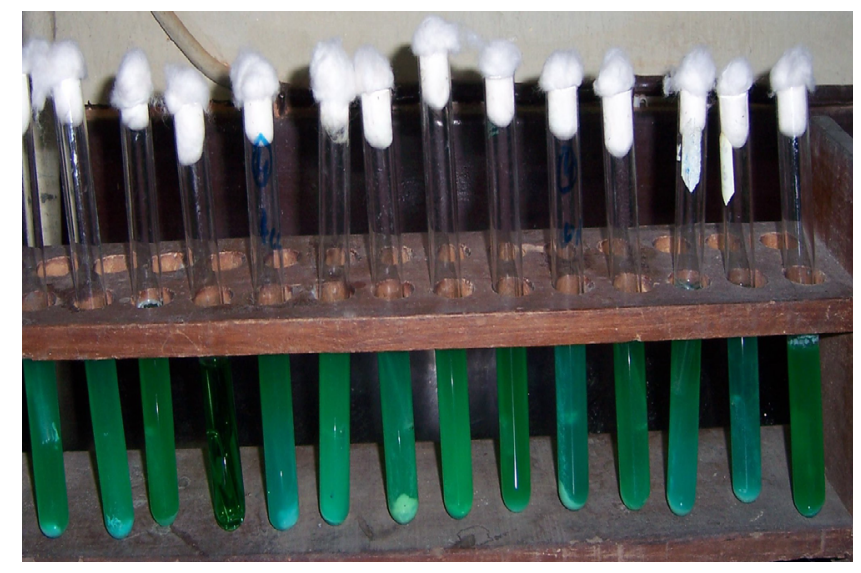

Figure 2. Confirmed test
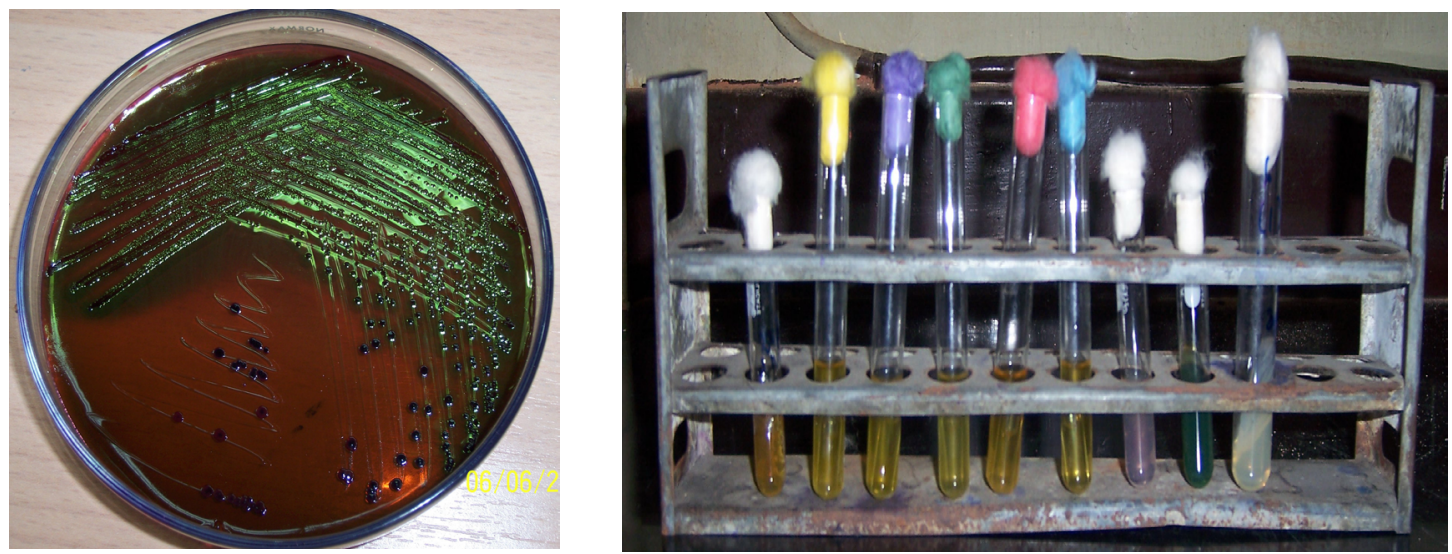

Figure 3. Escherichia coli on eosin methylene blue agar and biochemical test (completed test)

\section{RESULTS}

Escherichia coli were found at all points studied in the Angke River. The MPN of total and fecal coliform and other microorganisms isolated at the eight sampling locations is shown in Table 2. At Duri Kosambi, the microorganisms found were the most variable i.e. E. coli, Klebsiella oxytoca (K. oxytoca), Proteus mirabilis
(P. mirabilis) and Pseudomonas aeruginosa ( $P$. aeruginosa).

The lowest MPN was found at Pantai Indah Kapuk (MPN of total and fecal coliform were 81 and 0 respectively), followed by the estuary (Muara, at the outer side of the river mouth) where the MPN of total coliform $=430$ (Table 2 ). 
Table 2. Water quality at different sampling locations at the Angke River

\begin{tabular}{|c|c|c|c|c|}
\hline No. & Location & Test Result & Standard & Interpretation \\
\hline 1. & Duri Kosambi & $\begin{array}{l}\text { 1. MPN Total Coliform }=2400 \\
\text { 2. MPN Fecal Coliform }=0 \\
\text { 3. E. coli, K. oxytoca, } \\
\text { P. mirabilis, P. aeruginosa }\end{array}$ & \multirow{8}{*}{$\begin{array}{l}\text { A. Drinking water requirements } * \\
\text { 1. MPN Total Coliform }=0 \\
\text { 2. MPN Fecal Coliform }=0 \\
\text { 3. E. coli not found } \\
\text { B. Drinking water quality requirements } * * \\
\text { 1. MPN Total Coliform }=1000 \\
\text { 2. MPN Fecal Coliform }=100\end{array}$} & $\begin{array}{l}\text { Did not meet the } \\
\text { drinking water } \\
\text { requirements, but can } \\
\text { be used as clean water } \\
\text { ( } 2^{\text {nd }} \text { class water } \\
\text { quality)** }\end{array}$ \\
\hline 2. & Pesing Poglar & $\begin{array}{l}\text { 1. MPN Total Coliform }=2400 \\
\text { 2. MPN Fecal Coliform }=0 \\
\text { 3. E. coli,K. pneumoniae }\end{array}$ & & $\begin{array}{l}\text { Did not meet the } \\
\text { drinking water } \\
\text { requirements, but can } \\
\text { be used as clean water } \\
\text { ( } 2^{\text {nd }} \text { class water } \\
\text { quality)** }\end{array}$ \\
\hline 3. & Teluk Gong & $\begin{array}{l}\text { 1. MPN Total Coliform }=2400 \\
\text { 2. MPN Fecal Coliform }=0 \\
\text { 3. E. coli, K. oxytoca, P. mirabilis }\end{array}$ & & $\begin{array}{l}\text { Did not meet the } \\
\text { drinking water } \\
\text { requirements, but can } \\
\text { be used as clean water } \\
\text { ( } 2^{\text {nd }} \text { class water } \\
\text { quality)** }\end{array}$ \\
\hline 4. & Pantai Indah Kapuk & $\begin{array}{l}\text { 1. MPN Total Coliform }=81 \\
\text { 2. MPN Fecal Coliform }=0 \\
\text { 3. E. coli, E. aerogenes, } \\
\text { P. aeruginosa }\end{array}$ & & $\begin{array}{l}\text { Did not meet the } \\
\text { drinking water } \\
\text { requirements }(\mathrm{A}){ }^{*} \text { but } \\
\text { according to B it can } \\
\text { be classified as } 1^{\text {st }} \text { class } \\
\text { water quality that can } \\
\text { be used as drinking } \\
\text { water.** }\end{array}$ \\
\hline 5. & $\begin{array}{l}\text { Muara (left side of } \\
\text { river mouth) }\end{array}$ & $\begin{array}{l}\text { 1. MPN Total Coliform }=2400 \\
\text { 2. MPN Fecal Coliform }=0 \\
\text { 3. E.coli, P. mirabilis }\end{array}$ & & $\begin{array}{l}\text { Did not meet the } \\
\text { drinking water } \\
\text { requirements, but can } \\
\text { be used as clean water } \\
\text { ( } 2^{\text {nd }} \text { class water } \\
\text { quality).** }\end{array}$ \\
\hline 6. & Muara (river mouth) & $\begin{array}{l}\text { 1. MPN Total Coliform }=2400 \\
\text { 2. MPN Fecal Coliform }=0 \\
\text { 3. E. coli, E. aerogenes }\end{array}$ & & $\begin{array}{l}\text { Did not meet the } \\
\text { drinking water } \\
\text { requirements, but can } \\
\text { be used as clean water } \\
\text { ( } 2^{\text {nd }} \text { class water } \\
\text { quality).** }\end{array}$ \\
\hline 7. & $\begin{array}{l}\text { Muara (right side of } \\
\text { river mouth) }\end{array}$ & $\begin{array}{l}\text { 1. MPN Total Coliform }=2400 \\
\text { 2. MPN Fecal Coliform }=0 \\
\text { 3. E. coli,K. pneumoniae }\end{array}$ & & $\begin{array}{l}\text { Did not meet the } \\
\text { drinking water } \\
\text { requirements, but can } \\
\text { be used as clean water } \\
\text { ( } 2^{\text {nd }} \text { class water } \\
\text { quality)** }\end{array}$ \\
\hline 8. & $\begin{array}{l}\text { Muara (outer side of } \\
\text { river mouth) }\end{array}$ & $\begin{array}{l}\text { 1. MPN Total Coliform }=430 \\
\text { 2. MPN Fecal Coliform }=0 \\
\text { 3. E. coli, P.aeruginosa }\end{array}$ & & $\begin{array}{l}\text { Did not meet the } \\
\text { drinking water } \\
\text { requirements }(\mathrm{A}),{ }^{*} \text { but } \\
\text { according to B it can } \\
\text { be classified as } 1^{\text {st }} \text { class } \\
\text { water quality that can } \\
\text { be used as drinking } \\
\text { water } * *\end{array}$ \\
\hline
\end{tabular}

* Ministry of Health recommendation: Drinking Water Quality Requirements and Control SK Menkes RI No. 907/MENKES/SK/VII/2002 July 29 ${ }^{\text {th }}, 2002$

** Government regulation: Water quality handling and water contamination control. Peraturan Pemerintah Republik Indonesia No. 82/Tahun 2001 


\section{DISCUSSION}

In microbiological test, Escherichia coli (E. coli) was used as an indicator to test the quality of drinking water. Escherichia coli is an opportunistic organism that lived in human and mamal intestines as normal flora. The presence of E.coli in water indicates that the water is contaminated by human/mammal feces., ${ }^{2,3}$ The parameters of microbiology examination of water quality are: total and fecal coliform number. Bacteriological analysis can be done by two methods, i.e double tube and membrane filter method.

In this study we used the double tube method since this method is easier and effective for restless water, toxic water, and metal and phenol containing water. ${ }^{2,3}$

In membrane filter method, a water sample is passed through a sterile membrane filter that is housed in a special filter apparatus contained in a suction flask. Following filtration, the filter disc that contains the trapped microorganisms is aseptically transferred to a sterile Petri dish containing an absorbent pad saturated with a selective, differential liquid medium. After incubation, the bacterial colonies are counted. ${ }^{2,3}$

Clean water is different from drinking water. Not all clean water is save to be used as drinking water; instead, drinking water is definitely clean water. Nowadays, in big cities, even clean water is very difficult to be found. Only forty percents of middle to high economic class people in big cities in Indonesia have access to clean water. Poor people can only use river water which has bad odor. As the result of water condition and sanitation, diarrhea is the major cause of high mortality rate in these people, mostly in children. With the issue of global warming, healthy water crisis may get worst. Not only because of contamination with bacteria and waste, but also due to dry season that is predicted to happen in many Indonesian regions. ${ }^{6}$

Sixty five percents of Indonesian people live in Java, an island that the area is only $7 \%$ from all Indonesian land area. In java, there is only $4.5 \%$ water potential from total water potential in Indonesia. Sixty four of the 470 rivers in Indonesia (26 in Java) are now in crisis condition. Domestic waste enters the river, not to mention other wastes from industries, farm, and veterinary. River water quality monitoring in Indonesia is conducted twice a year. The result showed that dissolved oxygen (DO), biological oxygen demand
(BOD), chemical oxygen demand, fecal and total coliform bacteria in majority did not fulfill the $1^{\text {st }}$ class water quality. Based on biological parameter, MPN of fecal coliform in most river in crowded cities in Java are above the MPN for $1^{\text {st }}$ class water quality. For example: the Progo River (Central Java and Jogyakarta), the Ciliwung river (Jakarta), and the Citarum River (West Java). ${ }^{7}$ Most of the Ciliwung River is contaminated by domestic waste products and can not be classified as $1^{\text {st }}$ class water. Compared to Singapore, the Ciliwung River needs 18 years to recover its water to $1^{\text {st }}$ class water quality. ${ }^{8}$ Another study in Sukabumi (West Java) concluded that rivers in Sukabumi were contaminated by Escherichia coli that cause diarrhea. Fifteen rivers were contaminated with coliform and fecal coliform, and the MPN was above the standard for $3^{\text {rd }}$ class water quality. In those rivers, the MPN of total and fecal coliform were around 10,000/100 $\mathrm{ml}$ and 20,000/100 $\mathrm{ml}$ respectively. Nowadays people do not use river water in Sukabumi for drinking water anymore. ${ }^{9}$ From 23 samples taken, only 2 rivers showed MPN of total and fecal coliform below the MPN for $1^{\text {st }}$ class water quality standard, i.e. the Ciwalung and Ciparay Rivers which is located at the estuary. The contamination was due to lower awareness of people living in the environment (domestic waste).

Badan Pengendalian Lingkungan Hidup (BPLH) study in 33 locations of 13 rivers showed that in 2004 the river and soil water quality in Jakarta was contaminated with organic and inorganic compounds. As a result, the water did not fulfill the standard quality for drinking water, farming, fishery, and other city's activities. One strategy to solve these problems is to relocate people, move them far away from the water sources. ${ }^{10}$

Considering this condition, Tzu Chi Foundation has supported the relocation of people living along the Angke River to clean up the water, so that the water quality can be improved.

The result of our study at Duri Kosambi showed that this location was contaminated with $E$. coli originated from the environment, and not from human/animal feces. Other microorganisms observed such as K. oxytoca, P. mirabilis and P. aeruginosa are human pathogens/ opportunistic pathogens. ${ }^{2,11}$

At Pesing Poglar and Teluk Gong we found microorganisms that generally cause gastrointestinal and urinary tract infection in human (K.oxytoca,K. pneumoniae, and P. mirabilis. ${ }^{2,11}$ 
Almost all of the MPNs of total coliform of the locations studied were $2400 / 100 \mathrm{ml}$ which is higher than the standard quality for drinking water. This number is still lower compared to the total coliform in some rivers in Sukabumi which are not used as drinking water anymore. ${ }^{9}$

Even though the MPN of total coliform of water from Pantai Indah Kapuk and the outer side of the river mouth were the lowest, based on the Ministry of Health of the Republic of Indonesia recommendation (SK Menkes RI No. 907/MENKES/SK/VII/2002 July $29^{\text {th }}, 2002$ ), the water could not fulfill the requirements for drinking water. ${ }^{4}$ In general, the water at the Angke River is not recommended to be used as drinking water. However, the result using microbiology parameters showed that the water still can be used as clean water according to the government regulation which categorized the river water quality as $2^{\text {nd }}$ class water. People living in Pantai Indah Kapuk have a higher economic level than other areas. So, it can be assumed that they are more educated and have more knowledge and insight in hygiene and. sanitation.

At the estuary, the water has a higher salt concentration that inhibits coliform bacterial growth. This data is supported by the data from Sukabumi which showed that estuary areas had a lower number of total and fecal coliform. ${ }^{9}$

Thefore we recommended to prohibit people from using the Angke River water as drinking water, washing dishes, clothes or for making food and to prevent further water pollution/contamination using health promotion programmes.

In conclusion, the water quality of the eight sampling location is categorized as $2^{\text {nd }}$ class quality not recommended to be used as drinking water except the water from Pantai Indah Kapuk and estuary area that can be used as drinking water after boiling.

\section{Acknowledgment}

This research is a part of a multidisciplinary research in the Angke River supported by Tzu Chi Foundation.

\section{REFERENCES}

1. Shu Chuan Chiu. Restoring the Angke River. Tzu Chi Monthly. August 2003. No. 441. www.tzuchi.org/global/ projects/environmental_potection/stories_7.html. Downloaded 08/01/2008

2. Cappucino JG, Sherman N. Microbiology. A laboratory manual. $7^{\text {th }}$ ed New York: Pearson Education Inc; 2005.

3. Ministry of Health, the Republic of Indonesia. A guide for laboratory personnel in monitoring the drinking water quality, water treatment installation, collaboration project between the Republic of Indonesia and The Republic of Germany in Monitoring water quality. Directorate of water sanitation. GTZ PN 94.2253.6-001.00, Maret 2003.

4. Ministry of Health, the Republic of Indonesia. Keputusan Menteri Kesehatan Republik Indonesia tahun 2002, No. 907/MENKES/SK/VII/2002

5. The Republic of Indonesia. Peraturan Pemerintah tahun 2001, No. 82/Tahun 2001. Jakarta: The Republic of Indonesia; 2001.

6. Anon. Diambang krisis air sehat. www.depkes.go.id/ index. php?option=news\&task=viewarticle $\&$ sid $=2677$ Itemi. Downloaded 05/12/2007.

7. Dinar Rani Setiawan. Pelayanan air minum Jakarta dan pencemaran air. www.walhi.or.id/kampanye/air/privatisasi/ 051128_air_li. Downloaded 05/12/2007

8. Anon. Kualitas air sungai di Indonesia terus menurun. www.suaramerdeka.com/cybernews/harian/0608/16/nas8. htm. Downloaded 05/12/2007

9. Kemitraan Air Indonesia. Mayoritas sungai di kota Sukabumi tercemar Coli. www.inawater.com/news-Berita KAI. Downloaded 05/12/2007.

10. Nunuy Nurhayati. Kualitas air tanah dan sungai di Jakarta mengkhawatirkan. Tempo Interaktif, Selasa 12 Oktober 2004. www.tempointeractive.com/hg/2004/10/12/brk,2004101239.id html. www.Downloaded 10/10/2007.

11. Mims C, Dockrell HM, Goering RV, Roitt I, Wakelin D, Zuckerman M. Medical microbiology. $3^{\text {rd }}$ ed. Toronto: Mosby; 2004. 